\title{
Vine and Fruit Responses to Supplementary Irrigation and Canopy Management
}

\author{
M. G. McCARTHY*, R. M. CIRAMI* AND P. McCLOUD ${ }^{\S}$ \\ Department of Agriculture, South Australia, *Nuriootpa research and Advisory Centre, Nuriootpa; \\ ${ }^{\S}$ Biometrician, 25 Grenfell Street, Adelaide, South Australia. \\ The authors thank J. S. Evans and T. J. Glenn for technical assistance and Dr. B. G. Coombe for advice in the preparation of the manuscript.
}

Submitted for publication: April 1983

Accepted for publication: August 1983

\begin{abstract}
Drip irrigation at $0.0,0.2$ or 0.4 of weekly Class A Pan evaporation was applied to grapevines cv. Shiraz in the Barossa Valley of South Australia. Irrigation resulted in a significant increase in yield and vegetative growth but also significantly changed wine composition and wine spectral measures. Canopy management by shoot positioning and treatment with ethephon, both designed to increase fruit exposure to sunlight, resulted in significant but small changes in wine quality measures. The implications of these treatments for the improvement of wine quality from irrigated vines are discussed.
\end{abstract}

Due, in part, to summer drought, the Barossa Valley of South Australia is a region of low vine vigour and yield. Although water for irrigation is limited there is an increasing use of drip irrigation to help alleviate the sometimes severe moisture stress apparent by maturity; doubling of yield as a result of irritation is not uncommon. Smart et al. (1974) demonstrated that yields comparable with furrow irrigation could be maintained even with crop factors* of less than 0.5 , it should, however, be noted that the yield from their most severely stressed vine was at least twice that of non-irrigated vines of the same variety in the Barossa Valley. McCarthy (1981) demonstrated that significant increases in yield were possible with limited growing area climatically similar to the Barossa Valley. It was apparent, however, that the high plant chloride concentrations found in vine foliage and fruit may have been depressing the yield. McCarthy and Downton (1981) further demonstrated significant changes in wine chemical composition as a result of increased quantities of irrigation. Further work was considered necessary to ascertain the vine response to low levels of supplementary drip irrigation, using water containing low concentrations of chloride and total dissolved solids, and to ascertain whether wine chemical composition was altered as previously reported.

Smart et el. (1981) and Smart (pers. comm.) suggested that where vines have high vigour any resultant decrease in quality may be a consequence of failing to match vigour to adequate trellis, with concomitant changes in vine microclimate; they demonstrated that wine quality as measured by spectral and organoleptic assessment varied with fruit exposure to sunlight, e.g. shaded fruit increased wine $\mathrm{pH}$ and potassium, and reduced sugar concentration, wine colour density and fruit flavour.

Shulman et al. (1980) recognise that high vigour as a consequence of irrigation, nutrition, improved planting

* Smart defined crop factor as the ratio of irrigation plus effective rainfall to Class A pan evaporation for the period bud-break to harvest. material etc. are related to decreased quality. They suggest the use of growth regulators, such as ethephon, as a possible means of reducing excessive growth.

This study was undertaken to assess the effects of improving fruit exposure by physical and chemical means, on fruit and wine composition of vines receiving two levels of supplementary irrigation and an unirrigated control.

\section{MATERIALS AND METHODS}

Preliminary: Own-rooted Vitis vinifera cv. Shiraz were planted in 1974 on a Light Pass fine sandy loam, Dr2.23 (Northcote et al. 1954, Northcote 1965). The vines were planted $2.25 \mathrm{~m}$ apart in rows $3.7 \mathrm{~m}$ wide and trained on a single wire $1 \mathrm{~m}$ high. A second fruiting wire and a foliage support wire were installed in 1978, respectively 20 and $40 \mathrm{~cm}$ above the initial wire. Limited amounts of supplementary water were applied by drip irrigation during the growing seasons preceding the commencement of the irrigation trial.

The irrigation treatments imposed in spring 1978 were:

1. No irrigation.

2. Replacement of 0.2 of weekly Class A Pan evaporation (E).

3. Replacement of 0.4 of $\mathrm{E}$.

Quantities of water to apply on a weekly basis were determined using the formula:

litres $/$ vine $=([$ evaporation $(\mathrm{mm}) \times$ crop factor $]-$ rainfall $(\mathrm{mm}))$ $\times$ vine spacing $\left(\mathrm{m}^{2}\right)$.

Water applications were controlled with electrically operated time clocks and solenoid valves. In 1980 volumetric meters were installed to monitor actual quantities of water applied. A randomised block design of 4 replicates was used. Each plot consisted of six vines in each of three adjacent vine rows. These three treatment rows were buffered by vine rows on either side of the plots receiving $0.2 \mathrm{E}$ replacement irrigation. In each irrigation season treatments commenced after berry set and continued on a weekly basis to within 3-4 weeks of 
0.0E CONTROL

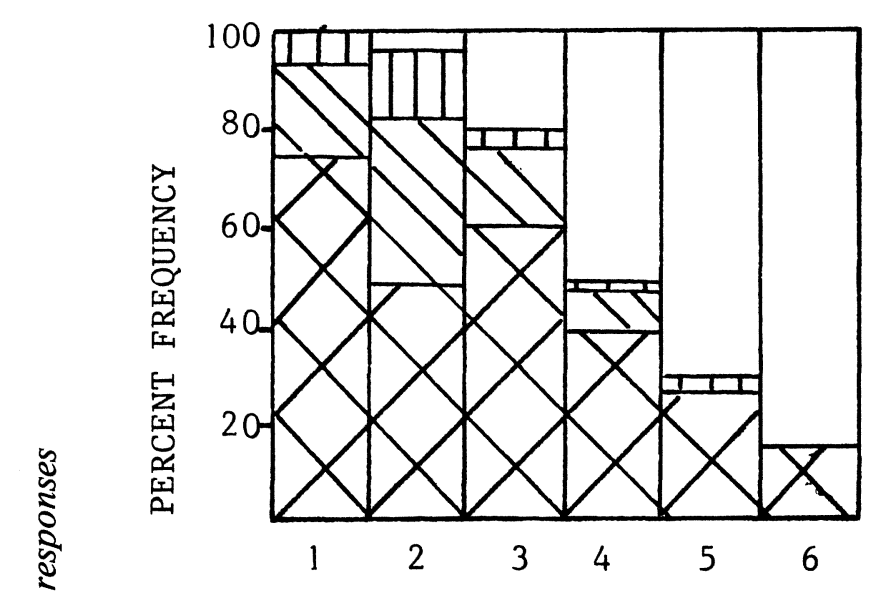

0.OE SLASH/SPRAYED

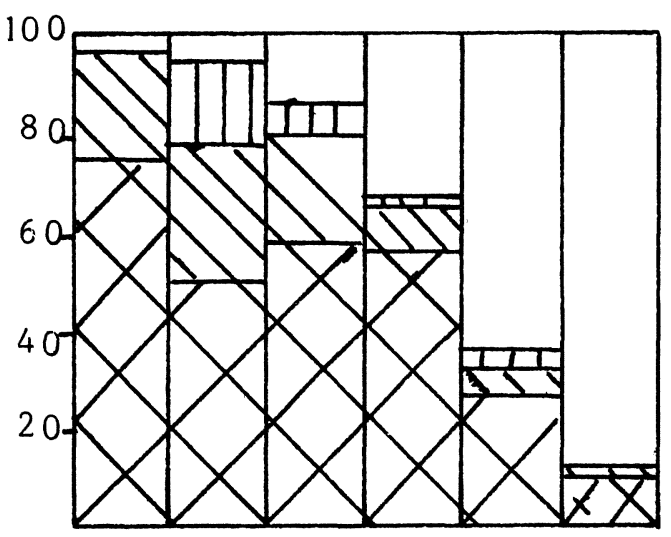

$\begin{array}{llllll}1 & 2 & 3 & 4 & 5 & 6\end{array}$
$0.20 \mathrm{E}$ CONTROL

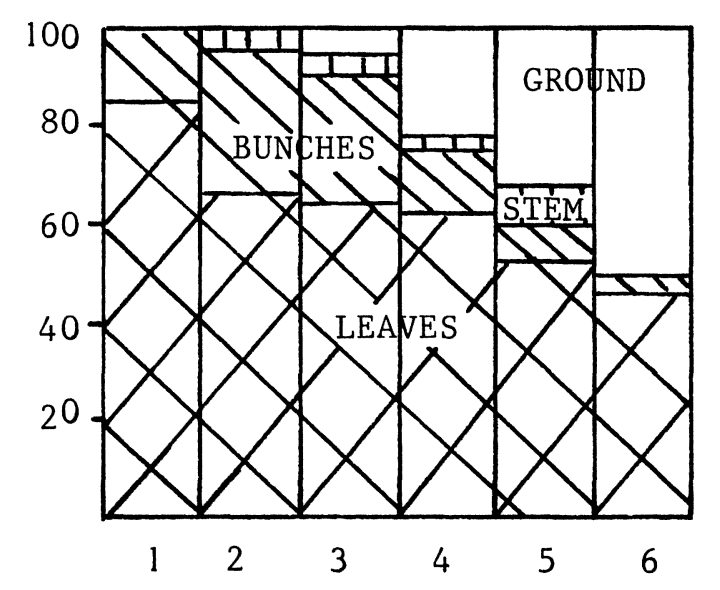

$0.20 \mathrm{E}$ SLASH/SPRAYED

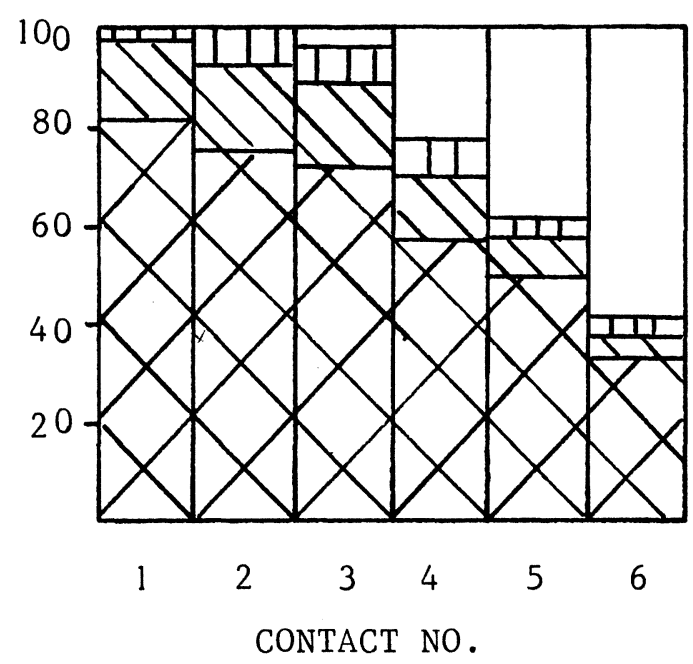

0.37 E CONTROL

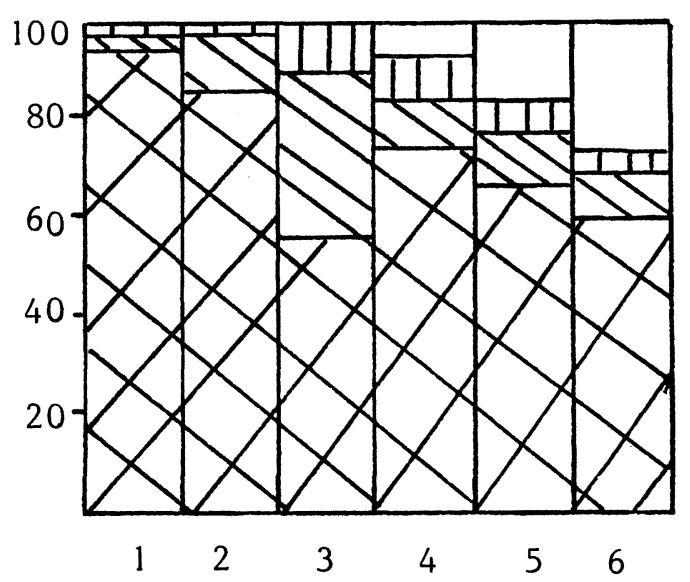

\subsection{E SLASH/SPRAYED}

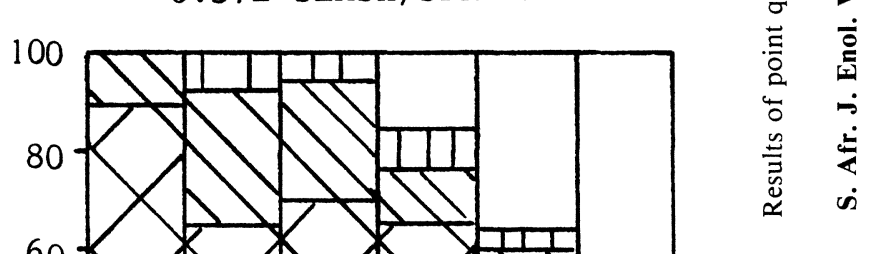


O. OE CONTROL

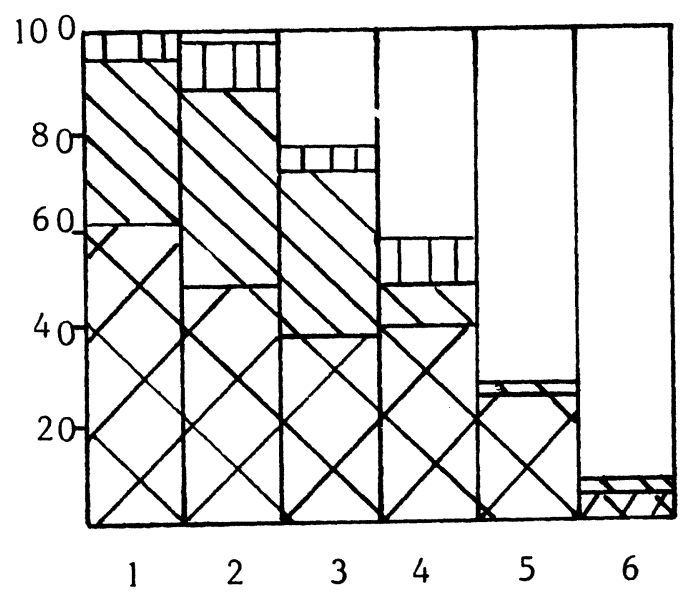

0.0E VERTICAL TRELLIS

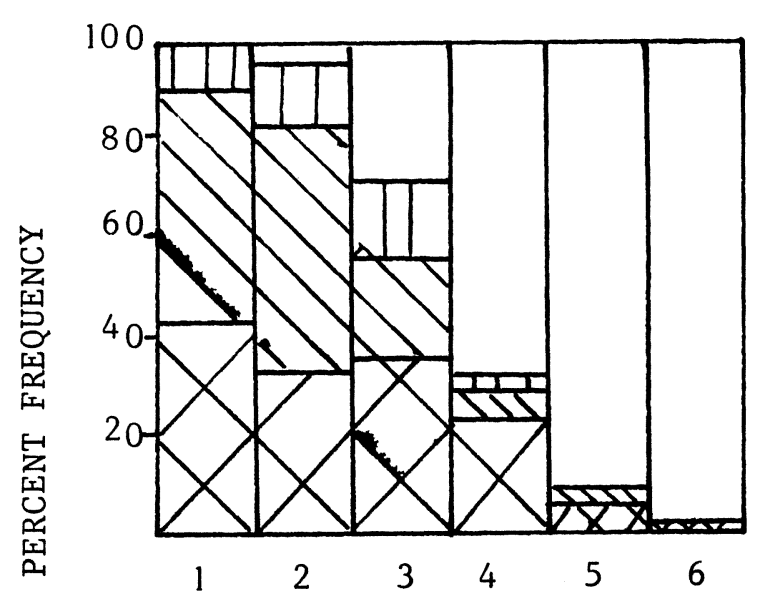

$0.22 \mathrm{E}$ CONTROL

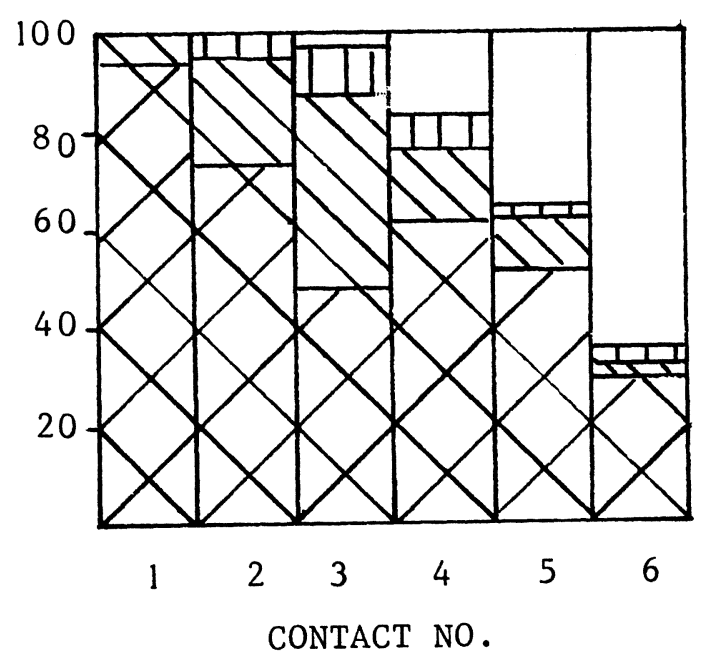

0.22E VERTICAL TRELLIS

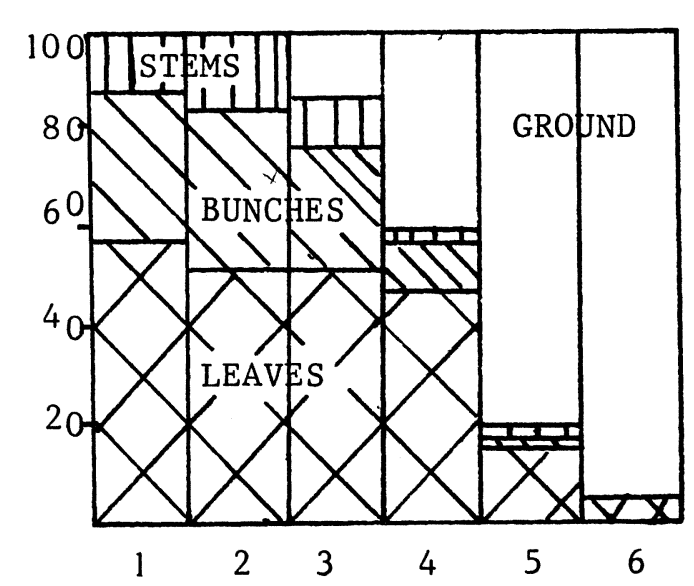

$0.36 \mathrm{E}$ CONTROL

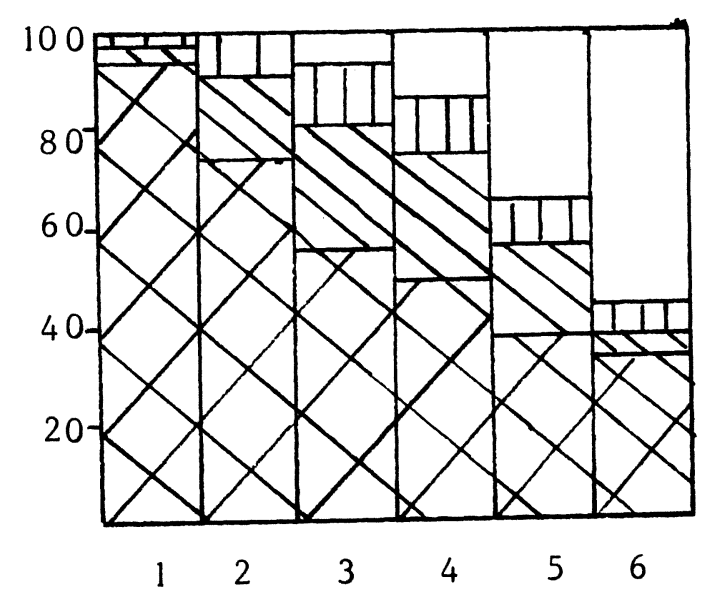

0.36E VERTICAL TRELLIS

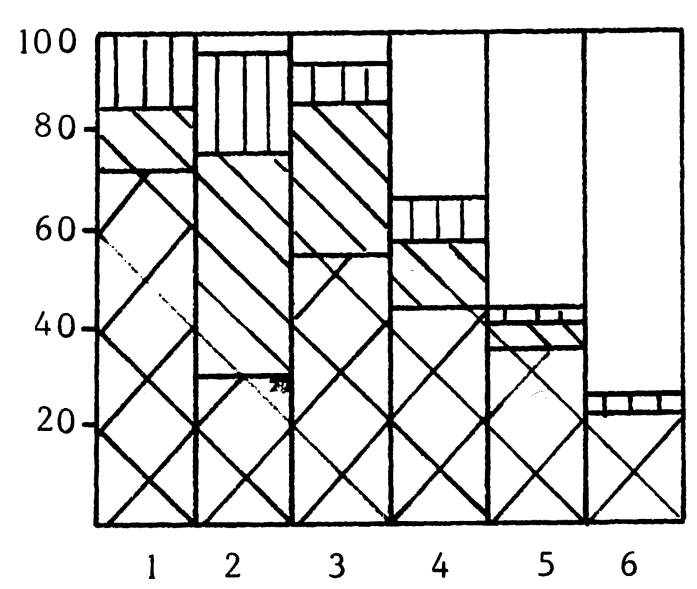




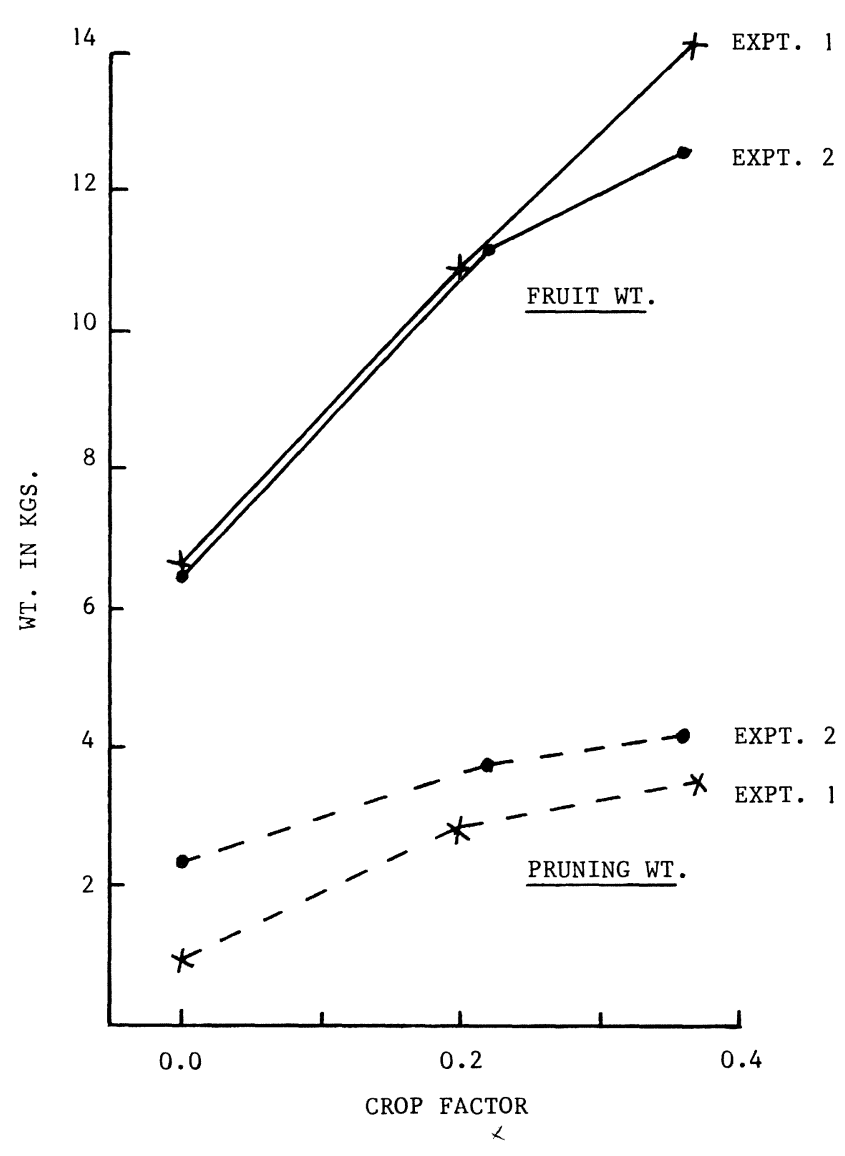

Fig. 2

Vegetative and fruit responses to irrigation for Expts. I \& II.

harvest. Vine and fruit response measurements at harvest 1979 and 1980 were done on vines at position 2 and 5 in each plot of the middle treatment row, and the mean used in subsequent statistical analysis. It was on the basis of these results that additional treatments were imposed.

Experiment I: In the winter of 1980 the main plot was split to allow a further treatment. The additional treatment applied across all irrigation treatments consisted of slashing back the canopy to approximately 6-8 nodes above the second bunch with a hand-held electrically operated hedge trimmer. This was done in midDecember, at which stage the berries were $2-3 \mathrm{~mm}$ diameter. The remaining canopy was immediately sprayed with Ethrel ${ }^{\circledR}$ (500 ppm ethephon) to the point of runoff with a hand-held spray gun.

An assessment of canopy density was made immediately before harvest by using a modified point quadrat method (Smart et al. 1981). The distribution of foliage, clusters and stems was assessed by passing a long fine rod at random into the canopy horizontally within the fruit zone at right angles to the row. Fifteen insertions were made per vine for each of the 3 vines in each split plot.

At harvest 50 random berry samples, taken from 10 bunches of the middle vine in each split plot, were collected to determine berry weight. Bunch number per vine and total fresh weight of fruit from the middle vine were then determined. All fruit picked was retained for winemaking. Fruit was held overnight at $2^{\circ} \mathrm{C}$ prior to crushing in a small crusher/destemmer. Approximately $8 l$ must subsamples were retained for fermentation, and from this further samples were collected for sugar, acid and $\mathrm{pH}$ determinations on centrifuged juice. Sugar ( ${ }^{\circ}$ Brix) was determined using a hand-held refractometer. Must $\mathrm{pH}$ and acidity (expressed as $\mathrm{g} / l$ tartaric acid) were determined on an automated end-point titration system. A 3\% inoculation of actively fermenting yeast (Australian Wine Research Institute selection of 729 Epernay yeast growing on Sultana juice) was made to the must. No metabisulphite additions were made as this is known to affect some spectral colour measurements (Somers \& Evans, 1976). Wines were fermented to dryness on skins to achieve maximum colour extraction and then hand pressed using a stainless steel sieve. After settling, a $750 \mathrm{ml}$ sample was taken and held at $20^{\circ} \mathrm{C}$ for 30 days prior to wine analysis. Wines were analysed on a UV spectrophotometer using the methods and derivations of Somers \& Evans (1976) to estimate total phenolics, colour density, and total and ionized anthocyanins. Potassium was determined by flame photometry.

Vegetative response of vines to the slashing treatment was assessed by the weight of prunings. Vines were cane pruned to the same number of nodes retained in the previous year, as this pruning level had resulted in the maintenance of a satisfactory balance of fruit and vegetative growth.

All data of Expt. I were statistically analysed as a split plot design.

Experiment II: In 1981 a trellis treatment was imposed across all three irrigation treatments with the aim of obtaining greater fruit exposure of training all foliage upwards. This was achieved by installing a series of $25 \mathrm{~cm}$ wide foliage T's above the existing fruiting vines. The first $T$ was approximately $20 \mathrm{~cm}$ above the top fruiting wire, and $\mathrm{T}$ pieces were $45 \mathrm{~cm}$ apart in the vertical plane. The highest $\mathrm{T}$ was approximately $2.75 \mathrm{~m}$ above ground level. The 6 vine plot of trellis $\times$ irrigation was further split to allow an ethephon treatment to be applied. At approximately 30 days after set ethephon (750 ppm adjusted to $\mathrm{pH} 6.9$ with phosphate buffer) was applied to one of the middle vines of each split-split plot. The mixture was applied to the terminal $20 \mathrm{~cm}$ of shoots with a knapsack sprayer.

Vine, fruit and wine responses were determined as for Expt. I. Canopy density assessments were done on the middle vine only; 20 insertions per vine were recorded. At pruning time total shoot length, number of nodes

TABLE 1

Selected meteorological and vine response measures for the 1980/81 and $1981 / 82$ seasons.

\begin{tabular}{|c|c|c|c|c|}
\hline \multirow[b]{2}{*}{ Theoretical crop factors used } & \multicolumn{2}{|c|}{ 1980/81 (Expt. I) } & \multicolumn{2}{|c|}{ 1981/82 (Expt. II) } \\
\hline & 0.20 & 0.40 & 0.20 & 0.40 \\
\hline $\begin{array}{l}\text { Total evaporation }(\mathrm{mm}) \text { recorded } \\
\text { during period of irrigation }\end{array}$ & \multicolumn{2}{|c|}{836.2} & \multicolumn{2}{|c|}{895.7} \\
\hline $\begin{array}{l}\text { Total rainfall }(\mathrm{mm}) \text { recorded for } \\
\text { period of irrigation }\end{array}$ & \multicolumn{2}{|c|}{51.4} & \multicolumn{2}{|c|}{30.1} \\
\hline Actual crop factors used & 0.20 & 0.37 & 0.22 & 0.36 \\
\hline Water applied $(\mathrm{mm})$ & 115.9 & 263.5 & 164.6 & 294.8 \\
\hline $\begin{array}{l}\text { Yield increase }\left(\mathrm{t} \mathrm{ha}^{-1}\right) \text { over } \\
\text { unirrigated }\end{array}$ & 4.85 & 8.75 & 5.20 & 8. \\
\hline $\begin{array}{l}\text { Yield increase }\left(\mathrm{t} \cdot \mathrm{ha}^{-1}\right) \text { per } \\
25 \mathrm{~mm} \text { irrigation }\end{array}$ & 1.05 & 0.83 & 0.79 & 0.75 \\
\hline
\end{tabular}


TABLE 2

Anova table of significance for treatment effects and interactions

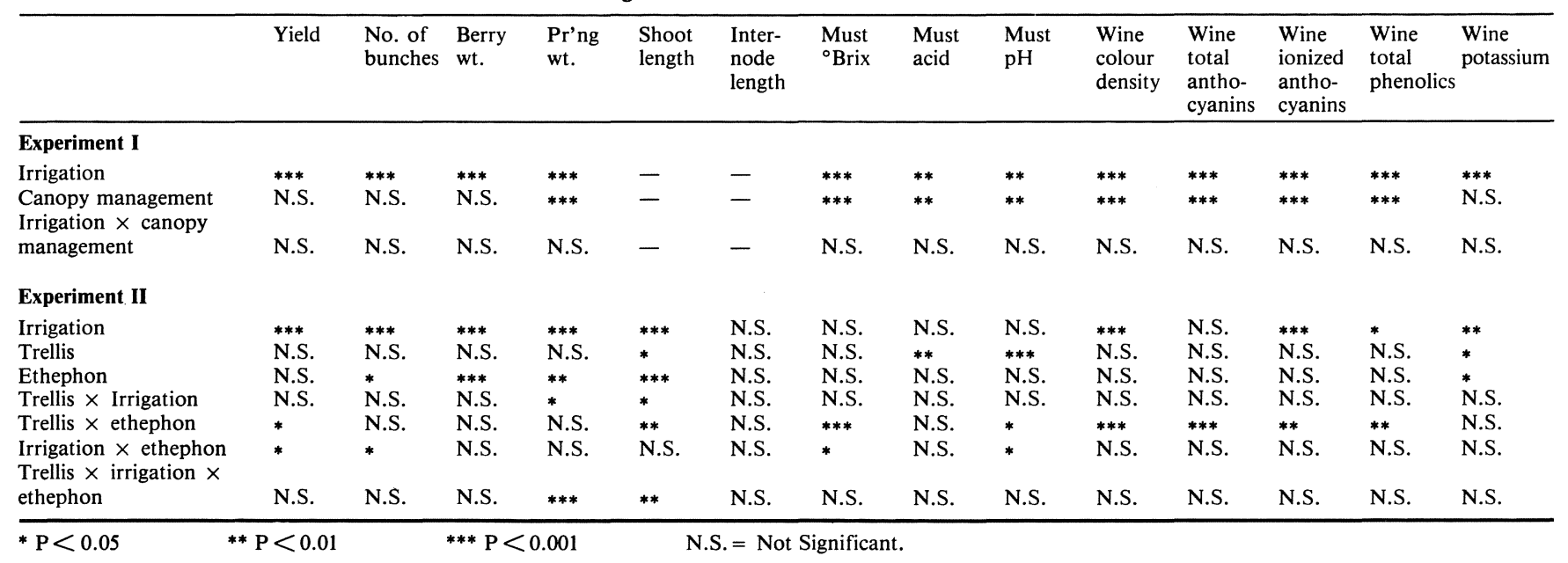

grown, number of shoots and total weight of prunings removed, were recorded. Wines were made as previously described. All date of Expt. II were analysed as a split-split plot design.

In the season after Expt. II the Merbein Bunch Count (Antcliff et al. 1972) was carried out to determine whether there were any carryover effects of irrigation, trellis or ethephon on bud burst or fruitfulness.

\section{RESULTS}

Quantities of water applied: Table 1 shows that actual crop factors used on the basis of water applied were close to the theoretical amounts initially calculated. The growing season 1981/82 was hotter and drier than $1980 / 81$, as shown by total evaporation and rainfall data; hence the quantities of water applied in Expt. II were greater.

Canopy configuration - Experiment I: Figure 1 shows the results of the point density analysis. Irrigation at $0.37 \mathrm{E}$ resulted in a particularly dense canopy with only $3 \%$ of the surface of the vine canopy being occupied by bunches, compared to $19 \%$ for unirrigated and $15 \%$ for the $0.20 \mathrm{E}$ treatment. At the second contact only $14 \%$ of touches were fruit contacts for $0.37 \mathrm{E}$ vines, as opposed to $34 \%$ and $30 \%$ for the unirrigated and $0.20 \mathrm{E}$ treatments respectively. The effects of slashing and ethephon application on fruit and leaf distribution were largest in the $0.37 \mathrm{E}$ treatment; with this treatment there was an increase of $7 \%$ and $14 \%$ in fruit contacts for the first and second contacts respectively. The effect of the canopy management treatment on the width of the canopy was also largest for $0.37 \mathrm{E}$ vines. For normal $0.37 \mathrm{E}$ vines $72 \%$ of the touches made at the sixth contact were parts of the vine, the remainder being gaps in the exterior surface of the vine canopy on the opposite side; after slashing, however, only $50 \%$ of the touches at the sixth contact were parts of the vine.

Experiment II: Irrigation resulted in a similar reduction in fruit exposure as in Expt. I, with only $1.4 \%$ of the surface of $0.36 \mathrm{E}$ vines being fruit, compared to $33.3 \%$ for standard unirrigated vines. Vertical training resulted in a significant increase in fruit exposure, the magnitude of this increase being greatest for irrigated vines. There did not appear to be any reduction in the width of unirrigated vines when trained vertically but a significant reduction in the width of the canopy of irrigated vines. The effects of ethephon on fruit exposure were not consistent: for $0.36 \mathrm{E}$ vines, application of ethephon appeared to increase fruit exposure on both trellis types; for $0.20 \mathrm{E}$ vines, fruit exposure was increased on the standard trellis but decreased on the vertical trellis; for unirrigated vines, ethephon decreased exposure on both trellis types (Data for ethephon effects not presented).

Fruit yield and its parameters: Because of the large amount of data, interactions between irrigation, trellis

TABLE 3

Yield and its components for Experiments I and II

\begin{tabular}{|c|c|c|c|}
\hline \multicolumn{4}{|l|}{ Experiment I } \\
\hline Main effects & $\begin{array}{l}\text { Yield } \\
\text { (kg/vine) }\end{array}$ & $\begin{array}{l}\text { No. of } \\
\text { bunches }\end{array}$ & $\begin{array}{l}\text { Wt. } 50 \\
\text { berries (g) }\end{array}$ \\
\hline \multicolumn{4}{|l|}{ Irrigation } \\
\hline $0.0 . \mathrm{E}$ & 6.96 & 78.6 & 46.3 \\
\hline $0.20 \mathrm{E}$ & 10.75 & 90.9 & 55.5 \\
\hline $0.37 \mathrm{E}$ & 13.80 & 108.8 & 63.6 \\
\hline LSD $(P<0.05)$ & 0.88 & 7.8 & 2.17 \\
\hline \multicolumn{4}{|l|}{ Canopy management } \\
\hline Normal & 10.58 & 92.8 & 55.7 \\
\hline Slashed and sprayed & 10.43 & 92.8 & 57.2 \\
\hline $\operatorname{LSD}(\mathrm{P}<0.05)$ & N.S. & N.S. & N.S. \\
\hline \multicolumn{4}{|l|}{ Experiment II } \\
\hline Main effects & $\begin{array}{l}\text { Yield } \\
\text { (kg/vine) }\end{array}$ & $\begin{array}{l}\text { No. of } \\
\text { bunches }\end{array}$ & $\begin{array}{l}\text { Berry } \\
\text { wt. (g) }\end{array}$ \\
\hline \multicolumn{4}{|l|}{ Irrigation } \\
\hline $0.0 \mathrm{E}$ & 6.68 & 80.2 & 0.97 \\
\hline $0.22 \mathrm{E}$ & 10.74 & 103.7 & 1.16 \\
\hline $0.36 \mathrm{E}$ & 13.58 & 125.9 & 1.26 \\
\hline LSD $(P<0.05)$ & 1.32 & 9.5 & 0.06 \\
\hline \multicolumn{4}{|l|}{ Trellis } \\
\hline Standard & 10.22 & 104.0 & 1.10 \\
\hline Vertical & 10.45 & 102.5 & 1.16 \\
\hline LSD $(\mathrm{P}<0.05)$ & N.S. & N.S. & N.S. \\
\hline \multicolumn{4}{|l|}{ Ethephon } \\
\hline Control & 10.12 & 98.2 & 1.08 \\
\hline Sprayed & 10.55 & 108.3 & 1.18 \\
\hline $\operatorname{LSD}(\mathrm{P}<0.05)$ & N.S. & 7.8 & 0.04 \\
\hline
\end{tabular}

N.S. $=$ Not Significant 
TABLE 4

Vegetative response of vines in Experiments I and II

\begin{tabular}{ll}
\hline \hline $\begin{array}{l}\text { Experiment I } \\
\text { Main effects }\end{array}$ & $\begin{array}{l}\text { Pruning wt. } \\
\text { (kg per vine) }\end{array}$ \\
\hline Irrigation & \\
$0.0 \mathrm{E}$ & 1.90 \\
$0.20 \mathrm{E}$ & 2.51 \\
$0.37 \mathrm{E}$ & 3.08 \\
LSD (P < 0.05) & 0.26 \\
Canopy management & \\
Normal & 2.81 \\
Slashed and sprayed & 2.18 \\
LSD (P < 0.05) & 0.19 \\
\hline \hline
\end{tabular}

\begin{tabular}{llll}
\hline \hline $\begin{array}{l}\text { Experiment II } \\
\text { Main effects }\end{array}$ & $\begin{array}{l}\text { Pruning wt. } \\
\text { (kg per vine) }\end{array}$ & $\begin{array}{l}\text { Shoot } \\
\text { length }(\mathrm{cm})\end{array}$ & $\begin{array}{l}\text { Internode } \\
\text { length (cm) }\end{array}$ \\
\hline Irrigation & & & \\
$0.0 \mathrm{E}$ & 2.24 & 112.3 & 7.72 \\
$0.22 \mathrm{E}$ & 3.38 & 131.2 & 7.82 \\
$0.36 \mathrm{E}$ & 4.03 & 143.9 & 7.64 \\
LSD (P 0.05) & 0.36 & 13.5 & N.S. \\
Trellis & & & \\
Standard & 3.02 & 115.3 & 7.49 \\
Vertical & 3.41 & 143.0 & 7.96 \\
LSD (P $<0.05)$ & $\mathrm{N} . \mathrm{S}$. & 24.1 & N.S. \\
Ethephon & & & \\
Control & 3.43 & 142.6 & 7.75 \\
Sprayed & 3.00 & 115.7 & 7.71 \\
LSD (P $<0.05)$ & 0.27 & 7.8 & N.S. \\
\hline N.S. Not Signiffi & & &
\end{tabular}

N.S. $=$ Not Significant

TABLE 5

Composition of fruit from Experiments I and II

\begin{tabular}{|c|c|c|c|}
\hline \multicolumn{4}{|l|}{ Experiment I } \\
\hline Main effects & ${ }^{\circ}$ Brix & $\begin{array}{l}\text { Titratable } \\
\text { acidity }\left(\mathrm{g} l^{-1}\right)\end{array}$ & $\mathrm{pH}$ \\
\hline \multicolumn{4}{|l|}{ Irrigation } \\
\hline $0.0 \mathrm{E}$ & 22.8 & 5.4 & 3.54 \\
\hline $0.20 \mathrm{E}$ & 22.6 & 5.1 & 3.61 \\
\hline $0.37 \mathrm{E}$ & 21.7 & 5.3 & 3.61 \\
\hline LSD $(P<0.05)$ & 0.5 & 0.2 & 0.05 \\
\hline \multicolumn{4}{|l|}{ Canopy management } \\
\hline Normal & 23.1 & 5.1 & 3.61 \\
\hline Slashed and sprayed & 22.3 & 5.4 & 3.56 \\
\hline $\operatorname{LSD}(\mathrm{P}<0.05)$ & 0.4 & 0.2 & 0.03 \\
\hline \multicolumn{4}{|l|}{ Experiment II } \\
\hline Main effects & ${ }^{\circ} \mathrm{Brix}$ & $\begin{array}{l}\text { Titratable } \\
\text { acidity }\left(\mathrm{g} l^{-1}\right)\end{array}$ & $\mathrm{pH}$ \\
\hline \multicolumn{4}{|l|}{ Irrigation } \\
\hline $0.0 \mathrm{E}$ & 25.3 & 4.2 & 3.78 \\
\hline $0.22 \mathrm{E}$ & 24.7 & 4.1 & 3.80 \\
\hline $0.36 \mathrm{E}$ & 24.6 & 4.1 & 3.80 \\
\hline $\operatorname{LSD}(\mathrm{P}<0.05)$ & N.S. & N.S. & N.S. \\
\hline \multicolumn{4}{|l|}{ Trellis } \\
\hline Standard & 25.2 & 3.8 & 3.88 \\
\hline Vertical & 24.5 & 4.4 & 3.71 \\
\hline $\operatorname{LSD}(P<0.05)$ & N.S. & 0.2 & 0.03 \\
\hline \multicolumn{4}{|l|}{ Ethephon } \\
\hline Control & 25.0 & 4.1 & 3.81 \\
\hline Sprayed & 24.8 & 4.1 & 3.79 \\
\hline $\operatorname{LSD}(\mathrm{P}<0.05)$ & N.S. & N.S. & N.S. \\
\hline
\end{tabular}

N.S. $=$ Not Significant and ethephon on yield, (and vegetative responses and fruit composition) are not presented, but the levels of significance of the main effects and interactions are given in Table 2.

Experiment I: Replacement of either 0.20 ot 0.37 of weekly Class A Pan evaporation resulted in significant increases in fruit weight per vine with the 0.37 treatment almost doubling yield (Table 3). This was due to a significant increase in both the number of bunches per vine and berry weight. The foliage management treatment did not have any significant effect on total fruit weight per vine or its parameters.

Experiment II: Yield response to 0.22 or 0.36 replacement irrigation resulted in similar yield increases to that recorded in Expt. I (Table 3). The increases were due, as before, to more bunches per vine and heavier berries. Training shoots in a vertical plane or spraying with ethephon did not affect total fruit weight but ethephon caused a significant increase in the number of bunches. Significant trellis and irrigation interactions with ethephon were apparent and due mainly to a significant ethephon effect on bunch number only at $0.36 \mathrm{E}$ irrigation. This increase accounted for the main treatment effect of ethephon on bunch number per vine. Ethephon application to foliage trained on the vertical trellis, resulted in a significant increase in fruit weight compared to unsprayed vines on the vertical trellis.

Vegetative responses - Experiment I: Irrigation resulted in a significant increase in the weight of prunings removed (Table 4). Vines slashed and sprayed with ethephon did not compensate for the foliage removed, as there was a significant reduction in the weight of prunings from these vines at pruning time. There were no irrigation $\times$ ethephon interactions on pruning weight (Table 2).

Experiment II: Similar responses were recorded in the total weight of prunings per vine as for Expt. I (Table 4). This was due to both an increase in the total number of shoots (as determined at pruning the previous year) and to significantly longer shoots. Irrigation did not alter the average internode length. Training shoots on a vertical trellis increased pruning weight per vine but non-significantly. While verticle training did not affect the average internode length, there was a significant increase in the average shoot length. Spraying shoot tips with ethephon resulted in a significant reduction in the weight of prunings, primarily through a significant reduction in the average shoot length. The average internode length was not affected by ethephon.

Significant interactions between ethephon or irrigation and trellis were apparent for shoot length. A significant interaction between trellis and irrigation was also recorded for pruning weight (Table 2). Vertical training of shoots of unirrigated vines or $0.22 \mathrm{E}$ vines did not affect pruning weight. However, vertical training of $0.36 \mathrm{E}$ vines resulted in significant increase in pruning weight. Trellis type did not affect vine response to ethephon, but only irrigated vines showed a significant response to ethephon. (See Table 2 for the level of significance of these interactions). 
TABLE 6

Analysis of wines made from fruit from Experiments I and II

\begin{tabular}{|c|c|c|c|c|c|}
\hline \multicolumn{6}{|l|}{ Experiment I } \\
\hline Main effects & $\begin{array}{l}\text { Colour density } \\
\text { (absorbance units) }\end{array}$ & $\begin{array}{l}\text { Total antho- } \\
\text { cyanins }\left(\mathrm{mg} . l^{-1}\right)\end{array}$ & $\begin{array}{l}\text { Ionized antho- } \\
\left.\text { cyanins (mg. } l^{-1}\right)\end{array}$ & $\begin{array}{l}\text { Total phenolics } \\
\text { (absorbance units) }\end{array}$ & $\begin{array}{l}\text { Potassium } \\
\left(\mathrm{mg} . l^{-1}\right)\end{array}$ \\
\hline \multicolumn{6}{|l|}{ Irrigation } \\
\hline $0.0 \mathrm{E}$ & 13.96 & 605 & 112.8 & 51.8 & 1465 \\
\hline $0.20 \mathrm{E}$ & 9.35 & 436 & 70.4 & 37.4 & 1625 \\
\hline $0.37 \mathrm{E}$ & 7.37 & 342 & 55.3 & 30.2 & 1650 \\
\hline LSD $(P<0.05)$ & 0.77 & 56 & 7.9 & 3.5 & 75 \\
\hline \multicolumn{6}{|l|}{ Canopy management } \\
\hline Normal & 11.16 & 516 & 87.5 & 43.4 & 1600 \\
\hline Slashed and sprayed & 9.29 & 406 & 71.6 & 36.2 & 1561 \\
\hline LSD $(P<0.05)$ & 0.59 & 49 & 6.1 & 2.4 & N.S. \\
\hline
\end{tabular}

Experiment II

Main effects

\begin{tabular}{|c|c|c|c|c|c|}
\hline \multicolumn{6}{|l|}{ Irrigation } \\
\hline $0.0 \mathrm{E}$ & 10.39 & 396.1 & 66.9 & 41.1 & 1526 \\
\hline $0.22 \mathrm{E}$ & 7.63 & 376.9 & 52.4 & 35.1 & 1726 \\
\hline $0.36 \mathrm{E}$ & 7.14 & 368.7 & 50.0 & 34.4 & 1713 \\
\hline LSD $(\mathrm{P}<0.05)$ & 0.88 & N.S. & 6.9 & 4.8 & 113 \\
\hline \multicolumn{6}{|l|}{ Trellis } \\
\hline Standard & 8.30 & 381.2 & 55.0 & 37.3 & 1748 \\
\hline Vertical & 8.47 & 380.0 & 57.9 & 36.4 & 1561 \\
\hline LSD $(\mathrm{P}<0.05)$ & N.S. & N.S. & N.S. & N.S. & 124 \\
\hline Control & 8.34 & 382.8 & 55.1 & 37.3 & 1704 \\
\hline Sprayed & 8.43 & 378.3 & 57.8 & 36.4 & 1605 \\
\hline $\operatorname{LSD}(P<0.05)$ & N.S. & N.S. & N.S. & N.S. & 86 \\
\hline
\end{tabular}

N.S. $=$ Not Significant

Based on the Merbein Bunch Count there was no carry over effects of ethephon on percentage bud burst or bud fruitfulness in the season after Expt. II (data not presented here), although there were trellis and irrigation effects.

Fruit composition - Experiment I: In contrast to the large effects of irrigation on fruit weight, the effect of irrigation on fruit composition was small. At the same time of harvest (all vines were harvested on the same day), vines irrigated to $0.37 \mathrm{E}$ were significantly less ripe than either $0.20 \mathrm{E}$ vines or unirrigated (Table 5) which were of similar ${ }^{\circ} \mathrm{Brix}$; even so, vines irrigated to $0.37 \mathrm{E}$ were only $1.1^{\circ} \mathrm{Brix}$ lower than unirrigated, irrespective of the approximate doubling in yield. Irrigation resulted in a significant increase in $\mathrm{pH}$, and at the same level of ripeness $0.37 \mathrm{E}$ vines may have had the highest must $\mathrm{pH}$. Vines irrigated to $0.20 \mathrm{E}$ had a significantly lower titratable acidity than unirrigated, and at similar ${ }^{\circ} \mathrm{Brix}$, $0.37 \mathrm{E}$ may have also been significantly lower in titratable acidity. The foliage treatment used in Expt. I significantly reduced ${ }^{\circ}$ Brix and increased acidity, suggesting a delayed ripening.

Experiment II: The grapes of Expt. II were riper than those of Expt. I when harvested. Irrigation at either $0.22 \mathrm{E}$ or $0.36 \mathrm{E}$ did not result in any significant changes in ${ }^{\circ} \mathrm{Brix}$, must $\mathrm{pH}$ or titratable acidity, although the trend was for irrigation to delay sugar accumulation, increased must $\mathrm{pH}$ and lower titratable acidity. Application of ethephon to the shoot tips had no significant effect on ${ }^{\circ}$ Brix, must acidity or $\mathrm{pH}$. Vertical training of shoots did not affect sugar accumulation but resulted in significantly higher must acidity and lower must $\mathrm{pH}$. Significant interactions between irrigation or trellis and ethephon were evident on ${ }^{\circ}$ Brix: ethephon on vines trained on the standard trellis resulted in a significant increase in ${ }^{\circ}$ Brix, whereas ethephon on vertically-trellised vines resulted in a significant reduction in ${ }^{\circ}$ Brix compared to

TABLE 7

Ethephon $\times$ trellis interactions on wine spectral measures (Experiment II)

\begin{tabular}{|c|c|c|c|c|c|c|c|c|}
\hline \multirow[b]{2}{*}{ Trellis type } & \multicolumn{2}{|c|}{$\begin{array}{l}\text { Colour density } \\
\text { (absorbance units) }\end{array}$} & \multicolumn{2}{|c|}{$\begin{array}{l}\text { Total anthocyanins } \\
(\mathrm{mg} / l)\end{array}$} & \multicolumn{2}{|c|}{$\begin{array}{l}\text { Ionized anthocyanins } \\
(\mathrm{mg} / \mathrm{l})\end{array}$} & \multicolumn{2}{|c|}{$\begin{array}{l}\text { Total phenolics } \\
\text { (absorbance units) }\end{array}$} \\
\hline & $\stackrel{+}{+}$ Ethephon & Ethephon & $\stackrel{+}{\text { Ethephon }}$ & Ethephon & $\stackrel{+}{\text { Ethephon }}$ & Ethephon & $\stackrel{+}{\stackrel{+}{\text { Ethephon }}}$ & Ethephon \\
\hline $\begin{array}{l}\text { Vertical } \\
\text { Standard }\end{array}$ & $\begin{array}{l}7.98 \\
8.88\end{array}$ & $\begin{array}{l}8.95 \\
7.73\end{array}$ & $\begin{array}{l}342.0 \\
414.7\end{array}$ & $\begin{array}{l}418.0 \\
347.7\end{array}$ & $\begin{array}{l}55.3 \\
60.2\end{array}$ & $\begin{array}{l}60.4 \\
49.8\end{array}$ & $\begin{array}{l}33.3 \\
39.4\end{array}$ & $\begin{array}{l}39.4 \\
35.2\end{array}$ \\
\hline $\begin{array}{l}\text { LSD }^{*} \\
\text { LSD }^{\S}\end{array}$ & \multicolumn{2}{|c|}{0.78} & \multicolumn{2}{|c|}{53.6} & \multicolumn{2}{|l|}{6.5} & \multicolumn{2}{|l|}{4.3} \\
\hline
\end{tabular}

* Use this LSD for horizontal comparisons.

$\S$ Use this LSD for vertical and diagonal comparisons. 
standard trellis, unsprayed vines (data not presented). Ethephon application to $0.36 \mathrm{E}$ vines resulted in delayed maturity but this may have been related to the yield increase caused by ethephon.

Wine colour spectral measures - Experiment I: Irrigation significantly reduced wine colour density, total and ionized anthocyanins, total phenolics and increased wine potassium (Table 6). Significant differences in these derived measures were recorded between the two irrigation treatments but there was no significant difference in potassium content of wines made from 0.20 or $0.37 \mathrm{E}$ vines. The canopy management treatment resulted in a significant reduction in wine colour density, total and ionized anthocyanins and total phenolics for all irrigation treatments. Canopy management did not affect wine potassium, and there were no significant irrigation $\times$ canopy management interactions.

Experiment II: Irrigation at either $0.22 \mathrm{E}$ or $0.36 \mathrm{E}$ resulted in a significant decrease in wine colour density, phenolics and ionized anthocyanins but there were no differences between the two levels of irrigation (Table 6). There was no irrigation main effect on total anthocyanins but a highly significant $(P<0.01)$ interaction between trellis and ethephon for wine colour density, total and ionized anthocyanins and total phenolics: in the absence of ethephon, training shoots on the vertical trellis resulted in a significant increase in wine colour density, total and ionized anthocyanins and total phenolics across all irrigation treatments (Table 7). Application of ethephon to vines on the vertical trellis negated these positive responses, whereas on the standard trellis application of ethephon resulted in significant increases in these parameters.

Wine potassium was significantly higher from irrigated fruit but there was no difference between the two irrigation levels. Training shoots on the vertical trellis resulted in a significant decrease in potassium concentration, as did spraying ethephon on shoot tips (Table 6).

\section{DISCUSSION}

Irrigation responses: Both yield and vegetative growth were significantly enhanced following irrigation at low levels of replacement evaporation - demonstrating (as did Smart et al. 1974) the responsiveness of vines to supplementary irrigation applied by the drip method. Smart et al. suggested that maximum benefit from limited supplies of irrigation water is obtained if application is frequent and at a low rate, as was done here. Over the two years of this investigation application of $100 \mathrm{~mm}$ of irrigation resulted in approximately a $38 \%$ increase in yield compared with unirrigated. This is similar to the result of Van Zyl \& Weber (1977), who demonstrated a $24 \%$ increase in yield over unirrigated for each $100 \mathrm{~mm}$ of irrigation applied at defined stages of growth. While the data presented here supports Smart's advocacy of frequent, small applications for maximum response, it is not possible to define unequivocally the best timing of irrigations as both the varieties under test and the yields were different in these investigations. The data do, however, demonstrate the favourable economic return possible through the controlled application of water.

Van Zyl \& Weber (1977) largely attributed the absence of wine quality differences to the fact that irrigated vines had similar ratios of fruit weight to vegetative weight. Figure 2 shows a nearly linear response of fruit weight and pruning weight to irrigation for control vines (Expt. I - 'normal vines'; Expt. II 'Standard trellis, control vines') in both experiments; in addition, the non-significant difference in average internode length in Expt. II further indicates that irrigation did not affect the fruit/vegetative growth ratios. Although the maintenance of this ratio may explain the absence of large differences in the fruit composition measures of sugar, acid of $\mathrm{pH}$ of the fruit, it does not account for the decrease in the quality related spectral measures of wine colour density, total and ionized anthocyanins, total phenolics and increased wine potassium as a result of irrigation. McCarthy \& Downton (1981) reported an increase in wine potassium as a result of increased levels of irrigation, and Hardie (1981) found that minimising water stress resulted in a significant increase in potassium content of newly made wines. Hardie suggested that the increase in berry potassium content appears to be the result of redistribution from leaves to fruit, and that high concentrations of potassium in low-stressed vines may be the indirect result of greater vegetative growth. The responses to ethephon reported here support this concept. Application of ethephon resulted in a significant reduction in growth as assessed by average shoot length, and it also resulted in a significant reduction in the potassium content of newly made wines. This effect was apparent for both irrigation treatments but was more pronounced for the $0.36 \mathrm{E}$ treatment with a $12 \%$ reduction in potassium content after spraying, compared to a $6 \%$ reduction for $0.22 \mathrm{E}$ vines.

Significant negative correlations were apparent between berry weight and both wine colour density and ionized anthocyanins for unsprayed vines in Expt. II $\left(r^{2}=0.50\right.$ and 0.27$)$. This correlation was, however, more significant on vertically-trellised vines $\left(\mathrm{r}^{2}=0.88\right.$ and 0.74$)$ than on standard-trellised vines $\left(\mathrm{r}^{2}=0.58\right.$ and $0.41)$; i.e. the decrease in wine colour density and ionized anthocyanins as berry weight increased, was more closely correlated if vines were trained vertically as opposed to the standard two-wire trellis. The reason why exposed berries should be more sensitive than shaded berries to a decrease in colour as berry size increased remains unclear.

Canopy management responses: The foliage management treatment imposed in Expt. I, while not affecting yield, had significant detrimental effects on wine quality by reducing wine colour density and a delay in maturity.

The changes in $\mathrm{pH}$ and acidity of these vines may probably be attributed to the delay in ripeness. The significant decrease in wine colour density is not considered to be accounted for by the small delay in maturity, but more as a result of foliage removal. This was not compensated for by subsequent growth, as it was inhibited by application of ethephon. Thus, while fruit exposure was significantly increased, as shown in the point density data (Figure 1), there was not a significant improvement in wine quality measures. It appears 
that the adverse effects of foliage removal and lateral shoot growth inhibition more than detracted from any possible improvement in wine colour density or, put another way, fruit exposure per se seems not to be an important factor affecting wine quality.

Vertical training of shoots in Expt. II to increase fruit exposure (as opposed to foliage removal as was done in Expt. I) resulted in some significant changes in fruit composition and vegetative growth characteristics. While there were no yield responses, vertically-trained shoots were longer as a result of more nodes grown. May (1966) reported similar results in Sultana when some shoots were trained vertically. The apparent lack of a trellis effect on wine spectral measures is accounted for by the highly significant trellis $\times$ ethephon interactions for these measures. In the absence of ethephon the vertical training of shoots resulted in an improvement in wine colour density, total and ionized anthocyanins and total phenolics. The magnitude of these increases was, however, small in comparison with the large increase in fruit exposure as assessed by point density measures. Where fruit exposure of irrigated fruit was increased to similar levels of unirrigated vines, there was not a concomitant increase in wine spectral measures; irrigated fruit was still of lower 'quality' than unirrigated. Smart et al. (1981) reported that at a fixed cropping level an increase in fruit exposure increased wine quality, whereas decreasing exposure by artificially increasing fruit shading by the leaves resulted in a decrease in quality. The data reported here tend to support this in that each cropping level, vertical training in the absence of ethephon did result in a significant although small improvement in colour density, anthocyanins and phenolics. Thus, while vine microclimate appears to be of some importance in determining quality, the microclimate modifications made in this experiment were not sufficient to maintain wine quality under irrigation, i.e. irrigation did have a direct negative effect on quality.

Improved biosynthesis of malic and tartaric acids as a result of a more efficient leaf canopy may account for the higher titratable acidity of vertically trained vines at harvest. A similar response has been observed in the variety Rhine Riesling (McCarthy unpub.) in which fruit on the vertical trellis had higher acidity levels even at the commencement of the ripening phase. Wine $\mathrm{pH}$ of vertically-trained shoots was also significantly lower. Somers \& Evans (1976) reported that wine $\mathrm{pH}$ has an important influence on the position of anthocyanin equilibrium: lower wine $\mathrm{pH}$ increases the degree of ionization of anthocyanins. This relationship may account for the increased concentration of ionized anthocynanins and hence colour for vertically trained vines in the absence of ethephon. As with organic acids, measured increased levels of total anthocyanins appear to be related to an improvement in the effective photosynthetic area.

Ethephon responses: The effects of ethephon per se in Expt. I are difficult to interpret because of the associated slashing treatment. The responses observed are, however, similar to those previously reported by Shulman et al. (1980) who found strong shoot inhibition when ethephon was applied after fruit set. Topping of vigorous vines after set in the absence of ethephon resulted in more total growth at harvest than control shoots, whereas applying ethephon to topped vines resulted in a significant reduction in total shoot length and the weight of prunings. The data presented here show (Expt. II) that ethephon reduced the average shoot length by approximately $28 \mathrm{~cm}$; this reduction was solely due to significantly fewer nodes developed, since the average internode length was unaltered.

Hardie et al. (1981) reported that a spray of ethephon at veraison to water stressed Zinfandel vines had no detectable effect on the rate of shoot elongation, whereas for vines under moderate or minimum levels of stress ethephon accentuated the decrease in shoot elongation rate during this growth phase. A similar response was evident for Expt. II where application of ethephon to unirrigated vines had no effect on pruning weight, whereas for $0.22 \mathrm{E}$ vines, ethephon significantly affected pruning weight on both trellis types. However, while ethephon resulted in a highly significant reduction in pruning weight on the vertical trellis by reducing the number of nodes per shoot, it significantly enhanced pruning weight when sprayed on vines grown on the standard trellis. This response suggests that ethephon treated vines grew larger diameter shoots. Shulman et al. (1980) reported, however, a slight decrease in cane diameter in response to ethephon.

As with trellis, the apparent lack of ethephon's main effects on wine spectral measures appears to be accounted for by the highly significant trellis $\times$ ethephon interactions for wine colour density, anthocyanins and phenolics. On standard trellised vines, fruit response to ethephon was as previously reported (Hardie et al. 1981), namely, an increase in ${ }^{\circ}$ Brix, and desirable increases in wine colour density, anthocyanins and phenolics for all irrigation treatments. Although significant within each irrigation treatment, ethephon application to irrigated vines with standard trellis did not increase these spectral measures to comparative levels of standard trellised, unsprayed, unirrigated vines.

The data presented here suggest that while a reduction in vegetative growth and increased fruit exposure have some beneficial effects on wine quality, their effects are small in comparison to the large effects of water status. It is, however, not apparent whether the positive response of irrigated vines to ethephon is due to increased exposure by reducing the shading effect of excess foliage, or a reduction in competition for photosynthetic products by the growing points. Neither of these interpretations can explain the cause of the apparent antagonism between vertical training and ethephon application. There are no similar responses recorded in the literature, and this result highlights the need for caution in the use of ethephon for vegetative growth control on vines that are vertically shoot positioned for increased sunlight interception. It seems unlikely that this result is an effect of ethylene, but it may be related to the effects of the chemical itself, as was recently suggested by Shulman et al. (1980).

\section{CONCLUSIONS}

The data presented demonstrate that irrigation, while having positive effects on yield and vegetative growth, has significantly adverse effects on wine quality measures. Control of vegetative growth or increasing 
fruit exposure to sunlight on irrigated vines caused only a small improvement in wine quality. Inverse correlations were found between berry size and wine colour density, suggesting that management practices that increase berry size may be detrimental to quality; thus some form of vine management which will reduce berry size of irrigated fruit (e.g. minimal pruning) may be a means of improving wine quality.

\section{LITERATURE CITED}

ANTCLIFF, A. J., MAY, P., WEBSTER, J. \& HAWKER, J., 1972. The Merbein bunch count, a method to analyse the performance of grapevines. Hort. Science 6, 196-197.

HARDIE, W. J., 1981. pH and acidity regulation in the vineyard by water supply. Proceedings of a seminar 'Grape Quality Assessment from vineyard to juice preparation' organised by the Australian Society of Viticulture and Oenology Inc., August 1981. 7-18.

HARDIE, W. J., JOHNSON, J. O. \& WEAVER, R. J., 1981. The influence of vine water regime on ethephon-enhanced ripening of Zinfandel. Am. J. Enol. Vitic. 32, 115-121.

McCARTHY, M. G., Irrigation of grapevines with sewage effluent. I. Effects on yield and petiole composition. Am. J. Enol. Vitic. 32, 189-196.

McCARTHY, M. G. \& DOWNTON, W. J. S., 1981. Irrigation of grapevines with sewage effluent. II. Effects on wine composition and quality. Am. J. Enol. Vitic. 32, 197-199.
MAY, P., 1966. Effect of direction of shoot growth on fruitfulness and yield of sultana vines. Aust. J. Agric. Res. 17, 479-490.

NORTHCOTE, K. H., RUSSELL, J. S. \& WELLS, C. B., 1954. Soils and land use in Barossa District, S.A. Zone 1. Nuriootpa area. CSIRO Soils and land use series No. 13.

NORTHCOTE, K. H., 1965. A factual key for the recognition of Australian soils. CSIRO Division of Soils Divisional Report $2 / 65$.

SHULMAN, Y., HIRSCHFELD, G. \& LAVEE, S., 1980. Vegetative growth control of six grapevine cultivars by spray application of (2-chloroethyl) phosphonic acid (Ethephon). Am. J. Enol. Vitic. 31, 288-293.

SMART, R. E., TURKINGTON, C. R. \& EVANS, J. C., 1974. Grapevine response to furrow and trickle irrigation. Am. J. Enol. Vitic. 25, 62-66.

SMART, R. E., ROBINSON, J. B. \& DUE, G. R., 1981. Manipulation of wine quality within the vineyard. Proceedings of a seminar 'Grape Quality - Assessment from vineyard to juice preparation' organised by the Australian Society of Viticulture and Oenology Inc., August 1981. 19-26.

SOMERS, T. C., \& EVANS, M. E., 1976. Spectral evaluation of young red wines: anthocyanin equilibria, total phenolics, free and molecular $\mathrm{SO}_{2}$, "chemical age". J. Sci. Food. Agric. 28, 279-287.

VAN ZYL, J. L. \& WEBER, H. W., 1977. Irrigation of Chenin blanc in the Stellenbosch area within the framework of the climatesoil-water-plant continuum. International symposium on the quality of the vintage. Cape Town, February 1977. 331-350. 